\title{
A SYSTEMATIC REVIEW OF THE INDIAN MINING REGULATIONS IN COMPARISON TO SASKATCHEWAN MINING LAW WhERE THE First Nations HoldS Mineral Title
}

\author{
P. DAWN MILLS
}

\begin{abstract}
The Indian Mining Regulations were adopted in 1954, revised in 1961, and amended in 1968 and 1978 as a means to promote mineral resource development on First Nation reserves, where First Nations hold title to the mineral resource. In this article, the Indian Mining Regulations, as part of a suite of regulations associated with the Indian Act, are outlined in relationship to Saskatchewan mining law. First is a general survey of First Nations' mineral titles across Canada where the Indian Mining Regulations apply. This article then discusses the application of these Regulations; compliance with provincial law; the disposition of minerals; permits; leases; and, finally, the assignment of royalties. It is recommended that a critical review of mineral resource potentials, exploration, mine permitting, and standards for environmental monitoring and reclamation be established prior to any assignment of the existing Indian Mining Regulations against any mineral resource development that occurs on First Nation lands or reserves.
\end{abstract}

\section{TABLE OF CONTENTS}

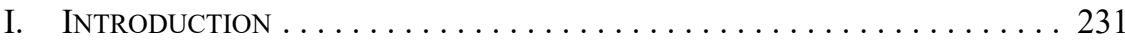

II. A General SuRVEy of First Nation

MineRAL TitLES IN CANADA $\ldots \ldots \ldots \ldots \ldots \ldots \ldots \ldots \ldots \ldots \ldots \ldots$

III. INDIAN MINING REGULATIONS

AND SASKATCHEWAN Mining LAW . . . . . . . . . . . . . 237

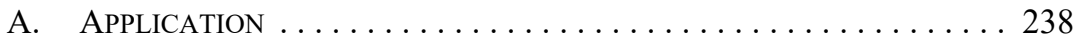

B. Compliance with Provincial LaW . . . . . . . . . . . 239

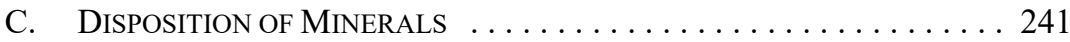

D. PERMITS . . . . . . . . . . . . . . . . . . . . . . . . . . . . . 242

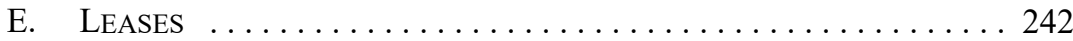

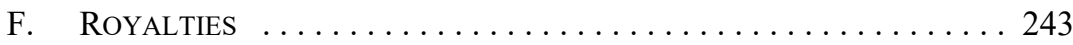

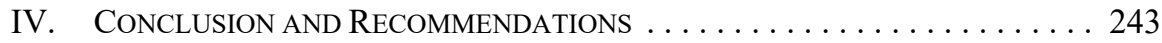

APPENDIX I: COMPARISON OF THE INDIAN MINING REGULATIONS WITH

SASKATCHEWAN Mining LEGISLATION AND REGULATIONS . . . . 246

APPENDIX II: TABLE OF TREATIES AND

CORRESPONDING MiNERAL TITLES . . . . . . . . . . . . . . . . . . . . . 259

APPENDIX III: ROYALTIES RESUlTING FROM VARIOUS ACTS

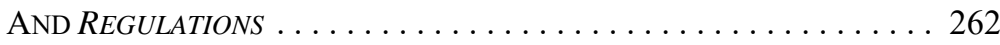

\section{INTRODUCTION}

Currently, mineral exploration and mining rights on some First Nation reserve lands are issued under the Indian Mining Regulations. ${ }^{1}$ The current Indian Mining Regulations are a parallel system of mining regulations directly associated with particular First Nations who

$\mathrm{PhD}$, Associate Director of Indigenous Natural Resources, Centre for Excellence for Sustainable Mining and Exploration, Lakehead University - Academic.

CRC, c 956. 
adhere both to Indian $\mathrm{Act}^{2}$ management, and hold mineral titles on their reserve lands. In terms of contemporary mining legislation, these regulations could be considered out of step with provincial standards related to prospecting; management of claims; exploration requirements; permitting process of both exploration and mining; and oversight of either prospecting, exploration, or a mining project. This article lays out the challenges of the Indian Mining Regulations in relation to Saskatchewan's mining law. However, only addressed by this article are mineral rights that First Nations have by means of Treaty or by federal-provincial agreements, and are cited to fall under the Indian Mining Regulations.

The Indian Mining Regulations in some aspects closely mirror provincial mining laws though out of date in a series of technical details. There are deviations. The main areas are related to the calculation and assessment of rents, royalty revenues, fees, or fines levied. In addition to these pragmatic economic concerns, the other important deficiencies are in the technical areas with the management of the claims, exploration, the mining permitting process, and the continual oversight of the mineral resource property during operations. Additionally, environmental standards as well as occupational health and safety standards are not referenced, leaving a certain degree of ambiguity as to the operational standards at any mine site. These gaps are made additionally problematic because there is no administrative unit in Indigenous Affairs that can legally carry the role of responsible authority. The combination of having an outdated mining regulatory framework and the lack of supporting environmental work place regulations and an administrative unit does not provide certainty for First Nations or corporations undertaking viable mineral resource projects on reserves.

Mining legislation, as regulatory law, ${ }^{3}$ carries with it a contractual relationship between the owner of the resource (either the federal/federal-First Nation, provincial government, or a private entity) and a company. This relationship is defined by permissions (a license or permit) to carry out prospecting, exploration, and mining activities. In addition, in either a license or permit, the environmental considerations and the terms related to rents, royalties, and fines are stipulated. ${ }^{4}$ In general, Canadian mining law covers a series of principal areas: ownership of the mineral, revenue sharing, and national security, with a range of supporting legislation and regulations associated with the corporate structure, raising of capital, employment policies, the environment, and health and safety at exploration camps and the mine site. In these areas, there are procedural duties, such as ensuring compliance by third parties and the mining company with the expectations laid out in either legislation or regulations. At the provincial and territorial level, this authority is granted by statute to an official, such as a Minister or Mining Recorder, subject to the guidelines outlined by legislation or regulations. In addition, there is an array of environmental acts and regulations designed to ensure that the ecosystem is considered throughout the mine life, and in the postclosure period. Mining legislation enables prospecting, exploration, and mining activities. Also incorporated into the permitting process and operation of mines are a series of federal

RSC 1985, c I-5.

In particular, regulatory law is concerned with ensuring that any mineral resource project undertaken is done in a manner that optimizes the benefit to the province or territory, while maintaining rigorous environmental standards. See Barry J Barton, Canadian Law of Mining (Calgary: Canadian Institute of Resources Law, 1993).

4 House of Commons, Standing Committee on Natural Resources, Streamlining Environmental Regulation for Mining: Final Report (November 1996) at 3 (Chair: Andy Mitchell). 
and provincial environmental laws and regulations that ensure ecological standards are maintained throughout the mineral resource development cycle. ${ }^{5}$ This includes is the business of mining, such as setting the standards to determine mineral property viability ${ }^{6}$ and the marketing of the minerals.

Historically, critiques of mineral resources related to First Nations have been limited to commentary about access to minerals for development, or the impacts of mineral development on First Nations associated with their access to either Treaty or Aboriginal rights. ${ }^{7}$ Other studies have focused on the recent endowment of mineral titles through First Nation Comprehensive Claims and Territorial Agreements. ${ }^{8}$ Although there has been the occasional mention of the Indian Mining Regulations in general treatises on Canadian mining law, ${ }^{9}$ there has not been a systematic review of them in comparison to provincial mining law in situations where a First Nation holds mineral title.

\section{A General Survey of First Nation Mineral Titles in CANADA}

In Canada, ownership of minerals usually rests with the Crown in Right of the Provinces, ${ }^{10}$ and is part of the discussion in the devolution process in the Yukon, ${ }^{11}$ the Northwest Territories, ${ }^{12}$ and in Nunavut. ${ }^{13}$ Mineral title may be held as part of "fee simple land ownership," 14 or First Nations may have mineral title as part of a Treaty, an Aboriginal Title

Ibid.

Standards of Disclosure for Mineral Projects, OSC NI 43-101 (30 June 2011).

Claudia Notzke, Aboriginal Peoples and Natural Resources in Canada (North York, Ont: Captus Press, 1994) at 197-225.

$8 \quad$ Anthony Knox, "Aboriginal Title and Mineral Development in Canada and Australia" (2000) 46 Rocky Mountain Mineral L Institute Proceedings 2-1.

9 Richard H Bartlett, "Provincial Jurisdiction and Resource Development on Indian Reserve Lands" in J Owen Saunders, ed, Managing Natural Resources in a Federal State: Essays from the Second Banff Conference on Natural Resources Law (Toronto: Carswell, 1986) 189 at 192; Richard H Bartlett, Indian Reserves and Aboriginal Lands in Canada: A Homeland (Saskatoon: University of Saskatchewan Native Law Centre, 1990) at 140-42; Richard H Bartlett, Subjugation, Self-Management and Self-Government of Aboriginal Lands and Resources in Canada (Kingston: Institute of Intergovernmental Relations, 1986) at 19-21. Constitution Act, 1982, ss 50, 51, 92A, being Schedule B to the Canada Act 1982 (UK), 1982, c 11.

Christopher Alcantara, Kirk Cameron \& Steven Kennedy, "Assessing Devolution in the Canadian North: A Case Study of the Yukon Territory" (2012) 65:3 Arctic J 328.

12 Northwest Territories Industry Tourism and Investment, Northwest Territories Mineral Development Strategy (2014), online: <https://www.iti.gov.nt.ca/sites/iti/files/nwt_mineral_development_strategy. pdf $>$.

13 Paul Mayer, Mayer Report on Nunavut Devolution (Toronto: Fasken Marteau DuMoulin, 2007).

14 Canadian settlers who purchased homestead lands from the Dominion of Canada prior to 1887, or from the Hudson Bay Company prior to 1902, acquired title to all mines and minerals, including hydrocarbons, natural gas, coal, and coal bed methane, under their land. The exceptions are: gold, silver, or other precious metals. In addition to the individuals who hold the mineral title as described above, there are others who hold what is known as a "split title." This mineral title would be held by individuals who purchased lands from the Canadian Pacific Railway (CPR) between 1902 and 1905 and this would include surface and subsurface minerals, with the exception of coal. Later, between 1906 and 1912, CPR sold land titles including surface and subsurface mines and minerals with the exception of coal, petroleum, and rock that could be used for ballast. The majority of such titles are in Alberta, with a few in Saskatchewan, and even fewer in Manitoba. See Freehold Petroleum \& Natural Gas Owners Association, "About Freehold Mineral Rights," online: <www.fhoa.ca/about-freehold-mineral-rights. html>. In British Columbia "freehold mineral rights" are referred to as "Crown granted mineral claims," and the holder's rights are defined in either the grant or the Mineral Act in force at the time. Crown granted mineral claims are no longer issued by British Columbia. See e.g. British Columbia, Mineral Titles: Information Update No $7-$ A Guide to Surface and Subsurface Rights and Responsibilities in British Columbia (Victoria: Mineral Titles, 6 September 2017) at 2-3. 
declaration, ${ }^{15}$ by agreement, or by land claim settlement. ${ }^{16}$ While some of these agreements give First Nations and Inuit people mineral rights through their Comprehensive Agreements, the regulatory scheme is located with the territorial government or provincial government. ${ }^{17}$

First Nations in the provinces of Alberta, Saskatchewan, and Manitoba are most likely to hold clear title to mineral resources. However, First Nations in parts of Nova Scotia, New Brunswick, Prince Edward Island, and Ontario may hold mineral title to some of their reserves. The mineral title for reserves in these provinces is dependent on the date of reserve creation, and how the reserve was initially created. Within First Nations, such as the Six Nations, ${ }^{18}$ the signatories of the Robson-Superior/Robinson-Huron, and First Nations from a selection of the numbered Treaties with reserves assigned before $1930,{ }^{19}$ mineral resources were either explicitly assigned to the community, or the Treaty is silent on the matter. On

15 See e.g. Delgamuukw v British Columbia, [1997] 3 SCR 1010 [Delgamuukw]; Tsilhqot'in Nation v British Columbia, 2014 SCC 44; Knox, supra note 8.

16 In the following agreements, either a provincial or territorial government owns the minerals, or does not relinquish control over the regulation of the mineral property. For example, in the Yukon, Northwest, and Nunavut Territories, the comprehensive claims agreements assert that mineral title, rents, and royalties from sales on a percentage of royalty revenue from mineral production are to be transferred to the First Nation community. In addition to holding title, the territory is expected to consult with the First Nations affected through a joint permitting process for the development. See Indian and Northern Affairs Canada, The Western Arctic Claim: The Inuvialuit Final Agreement (Ottawa: Minister of Indian Affairs and Northern Development, 1984) [Inuvialuit Final Agreement]; Indian and Northern Affairs Canada, Sahtu Dene and Metis Comprehensive Land Claim Agreement, vol 1 (Ottawa: Minister of Indian Affairs and Northern Development, 1983), ss 10, 22 [Sahtu Dene Agreement]; Indian and Northern Affairs Canada, Umbrella Final Agreement: Council for Yukon Indians (Ottawa: Minister of Indian Affairs and Northern Development, 1993), s 18.1.0 [Yukon Umbrella Agreement]; Indian and Northern Affairs Canada, Gwich'in Comprehensive Land Claim Agreement, vol 1 (Ottawa: Minister of Indian Affairs and Northern Development, 1992), ss 18.1.2, 19 [Gwich'in Agreement]; Land Claims and Self-Government Agreement Among the Tlicho and the Government of the Northwest Territories and the Government of Canada (Ottawa: Minister of Indian Affairs and Northern Development, 2003), ch 23, s 25 [Tlicho Land Agreement]; Déline Final Self-Government Agreement (Ottawa: Minister of Indian Affairs and Northern Development, 2015), ch 18, ss 18.1-18.2. In Quebec, mineral title on First Nations and Inuit settlement lands, including aggregates, is vested in the province of Quebec. However, soapstone and other minerals associated with the culture and arts of the James Bay Cree and Inuit is retained for their personal use. See e.g. The James Bay and Northern Quebec Agreement (Ottawa: Minister of Indian Affairs and Northern Development, 2008), ss 5.1.10(a)-(c) [James Bay Agreement]; The Northeastern Quebec Agreement (Ottawa: Minister of Indian Affairs and Northern Development, 1984), s 5.1.5.3. In British Columbia, through Treaty, First Nations on both existing reserves and acquired settlement lands, hold mineral title; the regulation of the mineral property is retained by British Columbia. It is expected that the First Nation defer the procedural aspects of exploration, mine development, and the collection of rents and royalties to the province of British Columbia. See e.g. Maa-nulth First Nations Final Agreement (Ottawa: Minister of Indian Affairs and Northern Development, 2013), ss 4.1.0, 4.1.3; Yale First Nation Final Agreement (Ottawa: Minister of Indian Affairs and Northern Development, May 2010), s 12.3. In Newfoundland and Labrador, the mineral title is retained by the province, but a percentage of the royalties are transferred from mineral production to the Labrador Inuit. Also, it is expected that the Inuit participate in the permitting and environmental assessment process. Like with the James Bay Agreement, ibid (see e.g. ss 5.1.2, 5.1.9.1, 5.1.0, 5.2.5), the Labrador Inuit hold title to soapstone and other rocks that are used for carving and other cultural activities, and need to ask permission to use aggregates. See Labrador Inuit Final Agreement (Ottawa: Minister of Indian Affairs and Northern Development, 2013), ss 4.4.1, 4.11, 4.13. However, in the Nunavik Inuit Land Claims Agreement (Ottawa: Minister of Indian Affairs and Northern Development, 2011), the Nunavik Inuit hold mineral title, but the administration is a tri-partied relationship between Nunavut, Newfoundland and Labrador, and Quebec. See e.g. ss 8.3.1(c), 9.1-9.4, 12.1-12.5.5, 15.1.2.

17 Graham White, "Treaty Federalism in Northern Canada: Aboriginal-Government Land Claims Boards" (2002) 32:3 Publius 89; James S Frideres, "Government Policy and Indian Natural Resource Development" (1984) 4:1 Can J Native Studies 51 at 54-55.

18 Canada, Indian Treaties and Surrenders: From 1680 to 1890, vol 1 (Ottawa: Brown Chamberlin, 1891) at 7 .

19 Alberta Natural Resources Act, SC 1930, c 3; The Railway Belt and Peace River Block Act, SC 1930, c 37 [Railway Belt Act]; The Manitoba Natural Resources Act, RSC 1930, c 29; The Saskatchewan Natural Resources Act, RSC 1930, c 41. In general, First Nations in Treaty 1, 2, 3, 4, 5, 6, 7, 8 (in Alberta and Saskatchewan only), 9, and 10 hold mineral titles on reserve lands. 
these reserves, the Indian Mining Regulations apply. However, due to the manner in which reserves were created after 1930, subsurface title can involve a provincial interest. This situation leads to uncertainty regarding who should regulate the exploration and surrender of minerals on First Nation reserve lands, and who benefits from their disposition. The mineral title for First Nations who have treaties is also unclear. For the majority of the reserves, provinces either own an interest in minerals or share the revenues from the disposition of First Nation minerals.

The federal government has sought to address these grey areas of ownership through federal and provincial mineral agreements in Ontario, New Brunswick, and Nova Scotia. These mineral agreements address some uncertainties by establishing legal frameworks for administering subsurface metallic minerals on reserves, and clarifying who benefits from their disposition. Where the provincial Crown has underlying legal title to the reserve minerals and no agreement exists, the federal Crown generally has difficulties in administering the minerals for the benefit of the First Nation. ${ }^{20}$ On many First Nation reserves, if the province holds the mineral title, then the First Nation may receive either half of the revenues from the mineral resource development, or nothing. ${ }^{21}$ In some instances, the federal government holds the title for the First Nation and all the revenue gained is for the benefit of the community. ${ }^{22}$ Also, some First Nations may have some reserves for which the title is held by the federal government for their benefit, while having other properties for which the province holds the mineral title.

For the majority of Alberta, Saskatchewan, and Manitoba reserves created before 1930, ${ }^{23}$ mineral title is vested in the federal Crown for the benefit of the First Nation. For these reserves, the management and disposition of the minerals (base and precious, coal, and salts) are pursuant to the Indian Mining Regulations and the income from the rents and royalties from the sale of the minerals goes entirely to the federal government for the benefit of the First Nation. For Alberta, ${ }^{24}$ Saskatchewan, ${ }^{25}$ and Manitoba ${ }^{26}$ reserves created after 1930, mineral title is still retained by the federal Crown, and the disposition and management of them are pursuant to the Indian Mining Regulations. However, the province in question is entitled to one half of all the income. Recently, with the Treaty Lands Entitlement process, First Nations have specifically chosen lands that hold mineral resource potential, or the First Nation has purchased the mineral title from the province. In Saskatchewan, the terms related to mineral title are set out pursuant to the Claim Settlements (Alberta and Saskatchewan) Implementation Act. ${ }^{27}$ Similarly in Manitoba, the Manitoba Claim Settlements Implementation $\mathrm{Act}^{28}$ drives treaty land entitlement settlements, and subsequently acquired

\footnotetext{
Barton, supra note 3 at 92 .

Ibid at $95-97$.

Ibid at 92-95, 98-99.

See e.g. Canada, Indian Treaties and Surrenders: From No. 281 to No. 483, vol 3 (Ottawa: CH Parmelee, 1912) (Treaty 1 at 282-89; Treaty 2 at 291-89; Treaty 4 at 313-21; and Treaty 8 at 293-300); Canada, Indian Treaties and Surrenders: From 1680 to 1890, vol 2 (Ottawa: Brown Chamberlin, 1891) (Treaty 5 at 16-23; Treaty 6 at 35-48; Treaty 7 at 56-62). Only in the area of Treaty 8 that falls in Alberta, Saskatchewan, and the Northwest Territories do the First Nations hold, or have the possibility of holding mineral title.

Alberta Natural Resources Act, supra note 19.

The Saskatchewan Natural Resources Act, supra note 19.

The Manitoba Natural Resources Act, supra note 19.

SC 2002, c 3.

SC 2000, c 33 .
} 
mineral titles. Many First Nations have purchased the surface only or have partial mineral interests in these lands. Often, the mineral title is already under the provincial regime, and Indigenous Affairs has to therefore provide surface access to the mining companies or the owners of the mineral interests, as part of the "Treaty entitlement" or "additions-to-reserve" creation. Likewise, for the First Nations who have signed onto the treaty land entitlement process, mineral title may or may not accompany the land selection. ${ }^{29}$

The map of mineral title holdings in Ontario is equally complicated. By the terms of the Robinson-Superior, ${ }^{30}$ Robinson-Huron, ${ }^{31}$ and Numbered Treaties (Treaties Three, ${ }^{32}$ Five,${ }^{33}$ and $\mathrm{Nine}^{34}$ ), First Nations hold title to all minerals and mines on their reserves. Mineral title is vested in the First Nations on lands prior to $1913,{ }^{35}$ but not on lands purchased after 1913. ${ }^{36}$ However, there are other pre-confederation treaties, as well as First Nation holdings that have been set aside by executive acts, and these are silent on mineral title. As such, gold and silver are reserved to the provincial Crown. ${ }^{37}$ In this situation, the metallic minerals, coal, and salt titles are vested in the province, with the income from mining divided equally between Ontario and the federal Crown with the federal Crown managing for the benefit of the First Nation. ${ }^{38}$ The Canada-Ontario Indian Lands Agreement of $1924^{39}$ and of $1986^{40}$ provide a mechanism whereby the province can waive to the First Nation either the mineral rights or royalties; or both. Recently, First Nations in Ontario have been going through a similar treaty land entitlement process as Alberta, Saskatchewan, and Manitoba First Nations, where an unencumbered third party mineral title has, in some cases, been transferred to the First Nation. ${ }^{41}$

In New Brunswick ${ }^{42}$ and Nova Scotia, ${ }^{43}$ mineral title remains with the provinces. However, the management and disposition of the minerals on reserves is addressed by the federal Crown in both New Brunswick and Nova Scotia under the Indian Mining Regulations, and all mineral income goes to the First Nation. ${ }^{44}$ Prince Edward Island claims mineral title to some reserves. That is, on the Morrell and Scotchfort Reserves, Prince

Ibid, s 11.

The Honourable Alexander Morris, The Treaties of Canada with the Indians of Manitoba and the NorthWest Territories Including the Negotiations on Which They Were Based (Toronto: Belfords, Clarke and Co, 1880) at $302-306$.

Ibid at $305-309$.

Ibid at $320-25$.

Ibid at 342-50.

James Morrison, Treaty Research Report: Treaty No 9 (1905-1906) (Ottawa: Treaties and Historical Research Centre, Indian and Northern Affairs Canada, 1986) at 27-32.

Public Lands Act, RSO 1990, c P.43, s 61(1).

An Act Relative to Mining, SO 1869 (32 Vict), c 34.

Ontario Mining Co v Seybold (1899), 31 OR 386.

Richard H Bartlett, "Mineral Rights on Indian Reserves in Ontario" (1983) 3:2 Can J Native Studies 245 at 263-67. See also Indian Lands Agreement (1986) Act, SC 1988, c 39 [Indian Lands Agreement]; Indian Lands Agreement (1986) Confirmation Act, 2010, SO 2010, c 1, Schedule 10.

An Act for the settlement of certain questions between the Governments of Canada and Ontario respecting Indian Reserve Lands, SC 1924, c 48 [Canada Ontario Reserve Act].

Indian Lands Agreement, supra note 38, Schedule, s 3 (especially ss 3(a)-(d), 3(f), 3(h)-(i), 4-7).

See e.g. Chapleau Creek Cree First Nation Treaty Land Entitlement Agreement, ss 7.1-7.5; Chapleau Creek Ojibwa First Nation Treaty Land Entitlement Agreement, ss 7.1-7.5; Misaanjigamiing First Nation Treaty Land Entitlement Agreement, ss 7.1-7.5.

New Brunswick Indian Reserves Agreement Act, SC 1959, c 47, Schedule [NB Reserves Act].

Indian Reserves of Nova Scotia Act, SC 1959, c 50, Schedule [NS Reserves Act].

NB Reserves Act, supra note 42, Schedule, s 5; NS Reserves Act, ibid, Schedule, s 5. 
Edward Island owns the rights, ${ }^{45}$ and on the Lennox Island No. 1 Reserve and Rocky Point Reserve, the mineral title is vested in the federal Crown for the First Nation ${ }^{46}$ and managed per the Indian Mining Regulations. Lastly, these regulations do not apply to reserves in British Columbia. ${ }^{47}$ In 1943, British Columbia entered into an agreement with Canada that passed on only the right to 50 percent of the mineral lease of any mine on a First Nation reserve in British Columbia, ${ }^{48}$ limiting the revenue stream to 50 percent of surface rents.

\section{INDIAN MINING REGULATIONS AND SASKatcheWAN Mining LaW}

Mineral resource development regulations on reserves falls under section 57(c) of the Indian Act, under which the Minister may make regulations "providing for the disposition of surrendered mines and minerals underlying lands" on listed First Nation reserves. ${ }^{49}$ The Indian Mining Regulations, ${ }^{50}$ brought into force initially in 1954 , enable third parties to access "naturally occurring metallic and non-metallic minerals and rock containing such minerals" where the First Nation holds mineral title. ${ }^{51}$ However, they do not apply to petroleum, natural gas, or other petroliferous minerals as these are administrated under the Indian Oil and Gas Act. ${ }^{52}$ The Regulations also do not apply to the extraction or sale of unconsolidated minerals such as placer deposits, gravel, sand, clay, rare earth minerals, marl, and peat. These substances are managed under section 58(4) of the Indian Act. ${ }^{53}$

In Saskatchewan, all exploration and mining is organized under The Energy and Mines Act, ${ }^{54}$ The Crown Minerals Act, ${ }^{55}$ The Mineral Resources Act, $1985,{ }^{56}$ and The Mineral

Richard H Bartlett, Indian Reserves in the Atlantic Provinces of Canada (Saskatoon: University of Saskatchewan Native Law Centre, 1986) at 49.

Ibid.

Indian Mining Regulations, supra note 1, s 3. In the Terms of Union, 1871, British Columbia agreed to convey "public lands," but reserved gold and silver. This was clarified in the British Columbia (AG) $v$ Canada (AG) (1889), 14 AC 295 (PC) [Precious Metals Case], where British Columbia claimed rights to gold and silver in the Railway Belt. See also The British Columbia Indian Lands Settlement Act, SC 1920, c 51; Railway Belt Act, supra note 19.

British Columbia Indian Reserves Mineral Resources Act, SC 1943-44, c 19 [BC Reserves Mineral Resources Act]; Indian Reserves Mineral Resources Act, SBC 1943, c 40. This agreement, as well as the Precious Metals Case, ibid, have discouraged any mineral resource development on reserves in British Columbia, except for gravel quarrying.

Supra note 2, s 57(c).

Supra note 1.

Ibid, s 2 .

RSC 1985, c I-7. All on-reserve petroleum, natural gas, and other petroliferous minerals for the exploration and development are covered by the Indian Oil and Gas Act, except for British Columbian First Nations.

3 Supra note 2. For placer deposits, gravel, sand, clay, earth, marl, and peat, a permit and lease are drawn up under section 58(4) of the Indian Act. However, the extraction and sale of any of the above minerals are regulated under Saskatchewan mining law. See e.g. The Sand and Gravel Act, RSS 1978, c S-5; The Quarrying Regulations, 1957, Sask Reg 553/67.

SS 1982-83, c E-9.10001. See also The Mineral Exploration Incentive Regulations, RRS c E-9.10001, Reg 1 [Exploration Incentive Reg].

SS 1984-86, c C-50.2. See also The Coal Disposition Regulations, RRS c C-50.2, Reg 3; The Lease of Spaces Regulations, RRS c C-50.2, Reg 7 [Lease Reg]; The Crown Mineral Royalty Regulations, RRS c C-50.2, Reg 29 [Crown Royalty Reg]; The Subsurface Mineral Tenure Regulations, RRS c C-50.2, Reg 30 [Subsurface Mineral Tenure Reg]; The Subsurface Mineral Regulations, 1960, Sask Reg 541/67; The Delayed Payment Charge Regulations,1970, Sask Reg 263/70; The Alkali Mining Regulations, Sask Reg 444/67; General Regulations (Tailings Disposal Area), Sask Reg 270/69.

56 SS 1984-86, c M-16.1 [Mineral Resources Act]. See also The Mineral Exploration Tax Credit Regulations, RRS c M-16.1, Reg 3 [Tax Credit Reg]; The Subsurface Mineral Conservation Regulations, RRS c M-16.1, Reg 5 [Subsurface Conservation Reg]. 
Taxation Act, $1983,{ }^{57}$ and their ensuing regulations. The Energy and Mines Act creates the ministry that assigns responsibilities to both the Minister and staff to manage Crown mineral assets. The Crown Minerals Act applies to all Crown minerals and mineral lands in Saskatchewan, setting out how the Crown grants minerals and lands to third parties, from exploration to production. Also included in The Crown Minerals Act is the ability of the Lieutenant-Governor General in Council to make regulations. The main purpose of the Mineral Resource Act is to manage all exploration, as well as development, conservation, and management of the primary production of mineral resources in Saskatchewan. Lastly, the Mineral Tax Act lays out the mineral taxation structure for all scheduled minerals produced in Saskatchewan. Each of the Acts has a variety of regulations that aid with the administration of Crown minerals and lands. Through The Saskatchewan Employment Act, ${ }^{58}$ The Mines Regulations, $2003^{59}$ address workplace safety and compliance for all surface and underground mines, the surrounding surface area, and standards for all equipment used at the mine. In addition to workplace and equipment safety, The Environmental Management and Protection Act, 2010, ${ }^{60}$ and The Mineral Industry Environmental Protection Regulations, $1996^{61}$ lay out the criteria and standards for environmental management at a mineral resource property.

\section{A. Application}

The Indian Mining Regulations are applied to situations where the First Nation holds title to minerals. Minerals in reserve lands are considered to be part of the land. As such, the revenue earned through surface rents, royalties, or mineral taxes is collected for the benefit of the First Nation community. There is an expectation that the First Nation surrender title to the mineral as a precursor for exploration, evaluation, or mining purposes ${ }^{62}$ Currently, this is not necessary. The First Nation may designate the land as a "conditional assignment" 63 until it is necessary to surrender the mineral at the commencement of production, or at the point of sale. There are additional arguments that suggest the "surrender of mineral" as precursor to either exploration or mining is premature. For instance, in Saskatchewan, through The Crown Minerals Act, the Crown retains the rights to the mineral until the point of sale. Section 27.2(2) states:

\footnotetext{
Notwithstanding the terms or conditions of any Crown lease, all spaces are the property of the Crown and remain the property of the Crown whether or not a Crown lease is issued for the Crown mineral within the space and whether or not the Crown mineral is produced, recovered or extracted from the space. ${ }^{64}$
} c M-17.1, Reg 5 [Sodium Chloride Tax Reg]; The Potash Production Tax Regulations, RRS c M-17.1, Reg 6 [Potash Tax Reg]; The Freehold Coal Production Tax Regulations, Sask Reg 39/84 [Coal Tax Reg]; The Mineral Rights Tax Regulations, 1998, RRS c M-17.1, Reg 7 [Mineral Rights Tax Reg]. SS 2013, c S-15.1.

RRS c O-1.1, Reg 2 [Sask Mines Reg].

SS 2010, c E-10.22 [EMPA].

RRS c E-10.2, Reg 7 [Mineral Environmental Protection Reg].

Indian Mining Regulations, supra note $1, \mathrm{~s} 3$.

Indian Act, supra note 2, s 55(2).

The Crown Minerals Act, supra note 55, s 27.2(2). 
This particular clause casts doubt on the necessity of Canada's requirement for the First Nation to either surrender the mineral, or surrender the surface land for the exploration or development of minerals resources, and questions whether this policy is sensible.

There is another question related to mineral ownership, and this is associated with whether an individual Band Member is in private possession of the particular-parcel of reserve land. This is a grey area in the law which is related to who can benefit and whether the Band is able to grant freehold rights. First, an argument can be made by the Band for the division of the revenue based on the degree of Band or individual investment. Another position would depend on whether or not the parcel was transferred to individual land ownership to secure capital funds, or if the individual holds a certificate of possession. Thus, proceeds from royalties can either be credited to the Band funds, or divided as determined by the Minister between the Band and "any Indian" in lawful possession of the lands, as per the Indian Act. ${ }^{65}$

It is recommended that reference to the surrender of minerals in the section "Application" be revised to stipulate how, and at what point the minerals in question are transferred from the First Nation to a third party. This should also include a clearer definition of the relationship between individual First Nation members, surface and subsurface rights, and the expectations of the Band related to the private subsurface rights. The last issue is related to the allocation of permits for exploration or mining that would be given out based on the proximity of existing mineral interests adjacent to a reserve.

\section{B. Compliance with Provincial LaW}

Section 4 of the Indian Mining Regulations stipulates that the mineral resource property on a reserve must conform to the provincial mining law in which the reserve is located. ${ }^{66}$ That is, section 4 defers to the law of the province in which the permit area or lease is situated, related to the "exploration for, or development, production, treatment and marketing of minerals. ${ }^{67}$ However, there is no mechanism or instrument, nor standards stated to achieve this. Saskatchewan, in both the The Crown Minerals Act, ${ }^{68}$ and the Mineral Resources Act, ${ }^{69}$ creates the ability to enter into agreements with Canada or First Nations. Although these two Acts are silent as to the purpose of such an agreement, it is likely this legislative tool could be used to bridge aspects of provincial mining law related to specific First Nation mineral properties. Such an agreement could easily assign the royalties, taxes, and rents to the federal government for the benefit of the First Nation, and set a schedule of fees owed to the provincial government for inspection services. These agreements would enable the incorporation of many contemporary stipulations related to provincial occupational health and safety at the mine site, as well as environmental standards that are triggered by companion legislation. ${ }^{70}$ However, this does not preclude the development of

Indian Act, supra note 2, ss 35(4), 58(4)(b), 58(5).

Indian Mining Regulations, supra note 1, s 4.

Ibid.

Supra note 55, ss 18.1-18.2.

Supra note 56, s 5.1 .

See e.g. Canadian Environmental Assessment Act, 2012, SC 2012, c 19, ss 5(1)(c)-5(2) [CEAA 2012];

EMPA, supra note 60; The Environmental Management and Protection (General) Regulations, RRS c E-10.22, Reg 1 [EMP General Reg]; The Environmental Management and Protection (Saskatchewan Environmental Code Adoption) Regulations, RRS c E-10.22, Reg 2 [EMP Code Adoption Reg]; Mineral Environmental Protection Reg, supra note 61. 
specific clauses in the Indian Mining Regulations that trigger environmental assessments, reviews related to mineral specific requirements for reserve based mineral resource developments. ${ }^{71}$ Lastly, provincial and territorial governments have existing administrative structures and practises directly related to managing mineral resource properties that are lacking in Indigenous Affairs. ${ }^{72}$ At the same time, any agreement would have to stipulate that any rents, royalties, or taxes are for the benefit of the First Nation, and that any administrative or inspection services would be on a "fee-for-service" basis taken up by Canada.

It is possible for provincial legislation to be incorporated as federal law through the construction of regulations by means of the First Nations Commercial and Industrial Development Act. ${ }^{73}$ The current trend has, however, been to create individual regulations for specific projects ${ }^{74}$ requiring a tripartite agreement between Canada, the province in question, and the First Nation. ${ }^{75}$ The FNCIDA assumes that the province in question will be a cooperating partner in lending its legislation, regulations, oversight, and management of the project without a guarantee of part of the royalties, rents, or taxes generated from the mine. The FNCIDA, through the creation of a specific regulation, adopts legislation, regulations, and administration that is not available within the federal government. ${ }^{76}$ This strategy may enable the Muskowekwan First Nation to proceed with the development of a solution potash mine on their home reserve. ${ }^{77}$ At the same time, this limits application to other Alberta,

See e.g. Preliminary Screening Requirement Regulations, SOR/99-12.

See e.g. Government of Saskatchewan, "Mineral Exploration and Mining," online: <www.economy. gov.sk.ca/Mining $>$.

SC 2005, c 53 [FNCIDA].

See e.g. Fort McKay First Nation Oil Sands Regulations, SOR/2007-79; Fort William First Nation Sawmill Regulations, SOR/2011-86; Haisla Nation Liquefied Natural Gas Facility Regulations, SOR/2012-293; Muskowekwan First Nation Solution Potash Mining Regulations, SOR/2017-47 [Muskowekwan Potash Reg].

See e.g. Muskowekwan Solution Potash Mining Project Tripartite Agreement, OC 571/2015.

See the following Acts and Regulations: The Energy and Mines Act, supra note 54; Exploration Incentive Reg, supra note 54; The Crown Minerals Act, supra note 55; Lease Reg, supra note 55; Crown Royalty Reg, supra note 55; Subsurface Mineral Tenure Reg, supra note 55; General Regulations (Tailings Disposal Area), supra note 55; Mineral Resources Act, supra note 56; Subsurface Conservation Reg, supra note 56; Tax Credit Reg, supra note 56; Mineral Tax Act, supra note 57; Mineral Rights Tax Reg, supra note 57.

Muskowekwan Potash Reg, supra note 74: incorporated by reference into this regulation are the following Saskatchewan Acts and Regulations: The Boiler and Pressure Vessel Act, 1999, SS 1999, c B-5.1; The Boiler and Pressure Vessel Regulations, RRS c B-5.1, Reg 1; The Electrical Code Regulations, RRS c E-6.3, Reg 16; The Electrical Inspection Act, 1993, SS 1993, c E-6.3; CEAA 2012, supra note 70; EMPA, supra note 60 (other than sections 13(3)-(4) and Division 1 of Part VI); EMP General Reg, supra note 70 (other than Part V); EMP Code Adoption Reg, supra note 70; The Fire Safety Act, SS 2015, c F-15.11 (other than section 34); The Gas Inspection Act, 1993, SS 1993, c G-3.2; The Ground Water Regulations, Sask Reg 172/66; The Hazardous Substances and Waste Dangerous Goods Regulations, RRS c E-10.2, Reg 3; Mineral Environmental Protection Reg, supra note 61; Mineral Resources Act, supra note 56 (other than the definition of Crown mineral lands in section 2(1)(c)); Sask Mines Reg, supra note 59; The Occupational Health and Safety Regulations, 1996, RRS c O-01.1, Reg 1 [OHS Reg]; The Oil and Gas Conservation Act, RSS 1978, c O-2 (other than section 17.041(7)); The Oil and Gas Conservation Regulations, 2012, RRS c O-2, Reg 6; The Passenger and Freight Elevator Act, RSS 1978, c P-4; The Pipelines Act, 1998, SS 1998, c P-12.1 (other than sections 13(1)-(2), 15-16); The Pipelines Regulations, 2000, RRS c P-12.1, Reg 1 (other than section 24); The Railway Act, SS 1989-90, c R-1.2 (other than sections 30(2)(a), 41, 42(1)-(2), 42(4)-(5), 44(2)); The Saskatchewan Employment Act, supra note 58 (other than Parts II, V-VIII); The Seismic Exploration Regulations, 1999, RRS c M-16.1, Reg 2; Subsurface Conservation Reg, supra note 56; The Uniform Building and Accessibility Standards Act, SS 1983-84, c U-1.2; The Uniform Building and Accessibility Standards Regulations, RRS c U-1.2, Reg 5; The Water Security Agency Act, SS 2005, c W-8.1 (other than sections 23-24, 38(1), 39-42, 64-66, 82(3), 82(6), 83(6), 83(8)-(9)); The Water Security Agency Regulations, RRS c W-8.1, Reg 1; The Waterworks and Sewage Works Regulations, RRS c E-10.22, Reg 3; The Workers' Compensation Act, 2013, SS 2013, c W-17.11 (other than sections 157, 159(1)). 
Saskatchewan, and Manitoba First Nations who have potash mineral potential by creating a "one-off" regulation specific to that property. ${ }^{78}$ Lastly, it is not clearly stated by the Indian Mining Regulations, nor the current Muskowekwan First Nation Solution Potash Mining Regulation, how the application of provincial law will affect the assignment of royalties or related mineral taxes and rents, which includes the calculation of exploration credits, ${ }^{79}$ reclamation bonding and management, ${ }^{80}$ security deposits, ${ }^{81}$ and the royalty or mineral tax rates initiation dates. ${ }^{82}$

\section{Disposition OF Minerals}

The right to look for minerals on a reserve arises through tender, or approval by Chief and Council. Exploration permits under the Indian Mining Regulations allow the holder to conduct exploration work ${ }^{83}$ or to enter a mining lease ${ }^{84}$ Final approval of either type of permit is at the discretion of the Division Chief, ${ }^{85}$ in consultation with the Band Council. Permits are issued for exploration and development, and a lease is necessary for mineral production. Exploration permits are issued for a term of one year with three renewal periods, granting the right to exploration up to four years, with extended periods at the discretion of the Division Chief. ${ }^{86}$ The exploration permit does not entitle the permit holder to "produce mineral," other than for test purposes. ${ }^{87}$ The disposition for both mineral rights, according to the Indian Mining Regulations, differs from Saskatchewan's requirements ${ }^{88}$ in that the proponent does not acquire the rights to explore for minerals under the traditional "free entry" system. ${ }^{89}$ In other words, the Division Chief invites tenders for mineral claims, ${ }^{90}$ and reserves the right to stipulate specific terms and conditions, to reject all proposals, ${ }^{91}$ or accept others on the recommendation of the Chief and Council. ${ }^{92}$ However, what is lacking is clarity of what is expected of the prospector during the tendering period and exploration period, ${ }^{93}$ as well as how reporting for assessment work is to be filed or calculated. ${ }^{94}$

See e.g. Cowessess First Nation Permit No: 6054188; Day Star First Nation Permit No: 367523; Ochapowace First Nation Permit Nos: 369276, 375202, 375203, and 5643-9-363 (not registered).

See e.g. Mineral Resources Act, supra note 56, ss 10(c)-(e), 10.1-10.5; Exploration Incentive Reg, supra note 54; Tax Credit Reg, supra note 56; The Crown Minerals Act, supra note 55, Schedule.

See e.g. Mineral Environmental Protection Reg, supra note 61, ss 12-22; General Regulations (Tailings Disposal Area), supra note 55.

See e.g. Mineral Environmental Protection Reg, ibid, ss 12-15.

See e.g. Mineral Taxation Act, supra note 57, Parts II-V; The Crown Minerals Act, supra note 55, ss 14-15, 16.01-16.03; Crown Royalty Reg, supra note 55, Part II, Division 2; Part III, Division 3; Part IV, Divisions 1-3.

Indian Mining Regulations, supra note 1, ss 7-16.

Ibid, ss $17-36$.

Ibid, ss 6.1, 38. The Regulations stipulate that Band Council approval is necessary only when the Division Chief proposes to issue a permit or lease in any means other than by tender (ibid, s 6 (1)), or when the Minister proposes to group a permit or lease area within an area, on another reserve, or outside a reserve (ibid, s 38).

Ibid, ss 7-9.

Ibid, ss 2(1), 16.

See e.g. Subsurface Mineral Tenure Reg, supra note 55, Part III, ss 7-17; Subsurface Conservation Reg, supra note 56 , ss $3-4$.

"Free entry" implies that the search for minerals can occur anywhere throughout Canada, given a few exceptions. The exceptions are: reserves, national and provincial parks, under pipelines, railways, highways, and private property (permission is required). See Nigel Bankes, "The Case for the Abolition of Free Entry Mining Regimes” (2004) 24:2 J Land Resources \& Envtl L 317.

Indian Mining Regulations, supra note 1, s 5.

Ibid, s 5 .

Ibid, s 6 .

See e.g. Subsurface Mineral Tenure Reg, supra note 55, Part VI, s 38; Subsurface Conservation Reg, supra note 56 , s 5.

Subsurface Mineral Tenure Reg, ibid, ss 11-14. 


\section{Permits}

A permit is issued to a proponent for exploration work at the early stages of mineral resource development. This permit is issued to explore for minerals in a specific area and stipulates what activities can be undertaken by the individual on the landscape. A standard requirement for exploration work is to undertake assessment work, and the value of this work is stated as part of maintaining the permit. ${ }^{95}$ Exploration permits are issued for a period, and at the end of the extension period, the permit is cancelled. In the case of the Indian Mining Regulations, although out-of-date with respect to the periods of the terms of the exploration permits and the fees and rents, ${ }^{96}$ the permit criteria follow general provincial mining legislation. That is, there are provisions for surface security deposits, ${ }^{97}$ and a criterion for assessment work. ${ }^{98}$ The Regulations provide for the removal of minerals at the exploration stage for test purposes only. ${ }^{99}$ Again, this is similar to Saskatchewan's legislation. ${ }^{100}$ Lastly, the Regulations provide for inspections, ${ }^{101}$ plans, ${ }^{102}$ and the surrender or cancellation of permits. ${ }^{103}$ However, it is unclear whether this refers to both the exploration permit and mining lease, or only to the lease. In addition, there is ambiguity as to who is responsible for carrying out these activities, other than the Division Chief (a position that no longer exists within Indigenous Affairs). Another difference is associated with the right of entry or access. The Indian Mining Regulations ${ }^{104}$ defer the permission process to be in accordance with any provisions that may be made by the Minister under the Indian Act. ${ }^{105}$

Another instrument under the Indian Act that is used for the allocation of permits, either for exploration or mining leases, for the expansion of an existing mineral operations that adjoins reserve lands, or to allow prospecting on a reserve, is the issuance of a permit by the Minister under section 28(2) of the Indian Act. This permit authorizes a person to occupy, use, or otherwise exercise rights on a reserve for a period not exceeding one year, or, with the consent of the Band Council, for longer periods. The application of this section is useful when an orebody extends under a First Nation reserve. However this permitting process is not referenced in the Indian Mining Regulations.

\section{E. LEASES}

For the production phase of the mining operation, a lease is drawn up. This lease is issued for a period of ten years, unless otherwise stipulated. ${ }^{106}$ The lessee is entitled to all the minerals found within the lease area, subject to the conditions of the lease. ${ }^{107}$ However, this lease, for mining purposes, is normally authorized by the "mineral surrender" prior to 1988 ,

Indian Mining Regulations, supra note 1, ss 13-14.

The Crown Minerals Act, supra note 55, s 16.03.

Indian Mining Regulations, supra note 1, s 11.

Ibid, ss $13-15$.

Ibid, s 16.

The Crown Minerals Act, supra note 55, s 13.

Indian Mining Regulations, supra note 1, s 42.

Ibid, ss 43-44.

Ibid, s 40 .

Ibid, s 41.

Supra note 2, s 28(2).

Indian Mining Regulations, supra note 1, s 23.

Ibid, ss 2(1), 20. 
or a "designation" after this date. ${ }^{108}$ In terms of provincial counterparts, when a mining permit is issued, the mineral is surrendered by the Crown to the proponent. ${ }^{109}$ Included in such an agreement would be the surface rents, royalty rates and calculations, ${ }^{110}$ reclamation security (insurance, bond, or cash security), environmental concerns, mitigation strategies, conditions in which a permit is forfeited, and a closure plan. ${ }^{111}$ In addition, the terms of the lease would provide the province with the assurance that the proponent will adhere to the various pieces of workplace safety and environmental legislation. ${ }^{112}$

\section{F. Royalties}

The lessee is obligated to pay royalties on all minerals, and the Regulations provide for a royalty rate of 5 percent of all gross revenue from the mineral output at the pithead, or the market value of the mineral output at the pithead, ${ }^{113}$ even if the minerals are not sold. Again, this condition is not aligned with the conventional assessment of royalties under provincial regimes, especially Saskatchewan. In the Indian Mining Regulations, the Division Chief is responsible for the setting of the royalty rate at the time of the lease. ${ }^{114}$ However, different rates may be set by tender under section $5,{ }^{115}$ in the lease under section $6,{ }^{116}$ or, yet again, in section $19 .{ }^{117}$ The point in time when the royalty is due is confusing. In the Indian Mining Regulations, pit edge estimates are used for royalty calculations, ${ }^{118}$ or the royalty rate may be assigned by agreement with the Division Chief. ${ }^{119}$ However, Saskatchewan defines when the royalty payment commences, ${ }^{120}$ and what can be deducted. ${ }^{121}$ Also, Saskatchewan has applied different rates for different minerals, with different conditions applied. ${ }^{122}$ Yet, the Indian Mining Regulations stipulate that when production begins, so does the application of the royalty, ${ }^{123}$ and no royalty calculation method is cited.

\section{CONCLUSION AND RECOMMENDATIONS}

The Crown expects the proponent who may explore or develop mineral properties on reserve to comply with the existing provincial and federal legislation and regulatory aspects of mineral exploration (including all environmental requirements) cumulating in the right to extract the metal or non-metal and sell the mineral in question. In addition to the adherence

Indian Act, supra note 2, ss 38(1)-(2), 41. Prior to the 1988 amendment of the Indian Act, in order for mineral resource development to proceed, First Nations were required to surrender the reserve lands (ibid, s 38 (1)). Now, under section 38(2) of the Indian Act, the Minister, with a Band Council Resolution and the results from a community referendum, will assign a "designation" to the land. This stipulates the terms of use of the land and the release conditions (ibid, s 41).

The Crown Minerals Act, supra note 55, s 4.

Ibid, ss 14-15.

Mineral Environmental Protection Reg, supra note 61, ss 12-16.

See e.g. OHS Reg, supra note 77; Sask Mines Regulations, supra note 59.

Indian Mining Regulations, supra note 1, ss 31(a)-(b).

Ibid, s 31 .

Ibid, ss 5,31 .

Ibid, ss 6,31 .

Ibid, ss 19,31 .

Ibid, s 32 .

Ibid, s 33 .

The Crown Minerals Act, supra note 55, s 14.

Ibid, ss 14-16.02; Crown Royalty Reg, supra note 55; Mineral Tax Act, supra note 57; Mineral Rights Tax Reg, supra note 57.

Crown Royalty Reg, ibid; Sodium Chloride Tax Reg, supra note 57; Potash Tax Reg, supra note 57; Coal Tax Reg, supra note 57; Mineral Rights Tax Reg, ibid.

Indian Mining Regulations, supra note 1, ss 34-35. 
to mining laws and regulations that outline the procedural aspects of the mining life cycle, the proponent needs to observe either the provincial or federal work place safety and environmental legislation that mining activities trigger. Again, deferring to alternative legislation or regulations (provincial or federal) without a clear responsible authority does not speak to sound management of a mineral resource property, nor will it give the proponent the required security of tenure to finance a mineral property.

Mining legislation and regulations must be able to create an environment where there is clarity about mineral ownership, manage any ecological risk, and maximize the benefit of the mineral revenue to the owners based on the strength of the orebody. Saskatchewan mineral resource legislation and regulations support the exploration and mining cycle. The current version of the Indian Mining Regulations is divergent from provincial legislation and regulations in a number of areas. First, at the claim phase, the Indian Mining Regulations do not stipulate the qualifications required of an individual or corporate body that is interested in seeking minerals, nor do they clearly indicate the responsibilities related to the procedures associated with early, intermediate, or advanced exploration. While exploration permits are issued through a tender process, they may be assigned directly from the Chief and Council or by the Division Chief (a position that no longer exists) — or not at all, even if the applicants meet the criteria. These processes suggest that there is a degree of ambiguity in the application process, as well as in the criteria for the actual evaluation of any application. This gives neither the Band, nor Indigenous Affairs, any indication of what the minimal standards are, or what the company expects its performance to be.

"Surrendering" the mineral as a pre-condition of exploration is nonsensical. Many viable mineral properties go undeveloped. For the First Nation to be put into this position as an initial prerequisite is counterintuitive to good business. However, by the time Saskatchewan has surrendered the mineral to a company, the mining plan has been scrutinized for production feasibility and ecological risk by the mining company endeavouring to undertake the project for financial solidity.

Additionally, Saskatchewan would have carefully evaluated the cost of production and mineral value in light of royalty calculations based on a feasibility plan, that would be part of the permitting process, as well as an environmental impact assessment. This environmental assessment would have outlined the ecological risks from the development's inception to post-closure, and put forth an analysis of the cultural, social, and economic impacts and benefits. This information is used to calculate the reclamation security. All this information enables Saskatchewan to make its decision to either endorse the mining project or disallow it. If Saskatchewan approves a mining project, the information collected as part of the permitting, from exploration onwards, is used in the evaluation of environmental and workplace safety monitoring at the mine site, as well as to ensure the accounting of sales against deductions is appropriate for royalty calculations. The choice that Indigenous Affairs currently has for the assessment of royalties of either the "pit edge," "sales at the pit edge," or deferring to the existing Saskatchewan (or provincial) royalty scheme, leaves a degree of uncertainty.

Besides managing the basic mining enterprise, there is no clear interconnection between the expectations of the mining regulations and other key federal environmental standards as 
articulated in related legislation and regulations. Although potential mining activities on a reserve trigger the Canadian Environmental Assessment Act, 2012, ${ }^{124}$ the Canadian Environmental Protection Act, 1999, ${ }^{125}$ the Fisheries Act, ${ }^{126}$ the Transportation of Dangerous Goods Act, 1992, ${ }^{127}$ the Explosives Act, ${ }^{128}$ and the Migratory Birds Convention Act, 1994, ${ }^{129}$ there is no coordinating agent to determine the degree to which the environmental assessment is to be conducted. Again, Indigenous Affairs, as the responsible authority, may not be best suited to undertake an evaluation of potential mining projects or environmental impacts.

It is recommended that mining legislation be enacted to cover the range of potential mining projects on a reserve. This would give First Nations a process to access a multitude of minerals. Clarity is required, especially related to the specific aspects of mineral resource development. This could be done through the creation of separate regulations to reflect the different aspects of mining from claim staking, exploration, disclosure, mine development, mine operations, mine closure, and for critical environmental oversight. More importantly, the regulations must be able to clearly set out how royalties are calculated, as well as a framework for the accountability of the production by a proponent. In addition, there needs to be clarification providing for the seizure and forfeiture of any minerals taken in contravention of any regulation.

Indian Mining Regulations should be drafted from a "Model Law" perspective that takes into account the special nature of the varied and potential mineral properties on First Nation reserves. Incorporated into such model law could be considerations such as: environmental concerns, social and economic impacts of mining, post-closure reclamation assessments, and optimum operation standards. In addition, consideration could be afforded to a wage scale that would not artificially inflate the benefit to the corporation and devaluate the royalty benefit. In considering the Crown and First Nation relationship, such an undertaking will require a mutually endorsed agency that would act as the responsible authority to ensure compliance, look after common mining administration, and provide oversight related to accountability associated with exploration credits, royalty assessments, payments, inspections for environmental and workplace safety, and the collection of rents, fines, or other penalties for mining projects on First Nation reserves - including the quarrying of aggregates. Activities, SOR/2012-147, ss 5.1, 9, 22; Prescribed Information for the Description of a Designated Project Regulations, SOR/2012-148.

SC 1999, c 33, Part 9.

RSC 1985, c F-14, ss 32, 35(2).

SC 1992, c 34; Transportation of Dangerous Goods Regulations, SOR/2001-286.

RSC 1985, c E-17; Explosives Regulations, 2013, SOR/2013-211.

SC 1994, c 22, ss 4(1), 28(1), 32 (1), 33; Migratory Bird Sanctuary Regulations, CRC, c 1036, s 9(1). 


\title{
APPENDIX I: \\ COMPARISON OF THE INDIAN MINING REGULATIONS WITH SASKATCHEWAN Mining LEgISLATION AND REgUlations
}

Appendix I lays out a clause-by-clause analysis of the Indian Mining Regulations against Saskatchewan mining laws and regulations. The purpose of this Appendix is to clearly illustrate the Indian Mining Regulations' deficiencies in light of the province of Saskatchewan's regulatory process for mineral exploration and mines.

\author{
Indian Mining Regulations \\ C.R.C., c. 956
}

\section{Regulations Providing for the Disposition of Surrendered Minerals Underlying Lands in Indian Reserves}

\section{Short Title}

1 These Regulations may be cited as the Indian Mining Regulations.

\section{Interpretation}

2(1) In these Regulations,

Act means the Indian Act;

assessment work means work performed that in the opinion of the Supervisor was performed for the purpose of discovering and developing minerals in a permit area or lease area and includes

(a) geological, geophysical, geochemical and similar surveys,

(b) core drilling, churn drilling and any other drilling method when used to provide geological information,

(c) removing overburden,

(d) drifting, crosscutting, shaft sinking, raising and similar underground work,

(e) road building, and

(f) any other type of work approved by the Supervisor;

Department means the Department of Indian Affairs and Northern Development;

Division Chief means the Chief, Oil and Mineral Division of the Development Branch of the Department or any person authorized by him

lease means a lease issued pursuant to section 5,6 or 19 granting the right to explore for, develop and produce minerals within the lease area;

lease area means the tract of land or location described in a lease; 
minerals means naturally occurring metallic and non-metallic minerals and rock containing such minerals, but does not include petroleum, natural gas and other petroliferous minerals or any unconsolidated minerals such as placer deposits, gravel, sand, clay, earth, ash, marl and peat;

Minister means the Minister of Indian Affairs and Northern Development;

permit means a permit issued under section 5 or 6 granting the right to explore for and develop minerals within the permit area;

permit area means the tract of land or location described in a permit;

permittee means a person who holds a permit;

person means a person who has attained the age of 21 years or a corporation registered or licensed in Canada or in any province thereof;

Supervisor means the Supervisor of Indian Minerals for the Oil and Mineral Division of the Development Branch of the Department, or any person authorized by him;

treatment means concentrating, smelting, refining or any similar process but does not include washing, screening, conveying, loading or other handling methods when they are not combined with treatment.

\section{Application}

3 These Regulations ${ }^{130}$ apply with respect to surrendered mines and minerals underlying lands in a reserve, but do not apply with respect to surrendered mines and minerals ${ }^{131}$ underlying lands in a reserve that is situated in the Province of British Columbia. ${ }^{132}$

\section{Compliance with Provincial Laws}

$4 \quad$ Every permittee and every lessee shall comply with the laws of the province ${ }^{133}$ in which his permit area or lease area is situated where such laws relate to exploration for, or development, production, treatment and marketing of minerals ${ }^{134}$ and do not conflict with these Regulations. ${ }^{135}$

Indian Act, supra note 2, s 57.

131 The Crown Minerals Act, supra note 55 ("[n]otwithstanding the terms or conditions of any Crown lease, all spaces are the property of the Crown and remain the property of the Crown whether or not a Crown lease is issued for the Crown mineral within the space and whether or not the Crown mineral is produced, recovered or extracted from the space," s 27.2(2)). This particular clause casts doubt onto Canada's requirement of either surrender of the mineral or surface land for the exploration or development of mineral resources by either third parties or the First Nation Community until the minerals in question are transferred to the corporate body for sale.

$132 \quad$ Precious Metals Case, supra note 47.

133 See e.g. The Energy and Mines Act, supra note 54; The Crown Minerals Act, supra note 55; Mineral Resources Act, supra note 56; Mineral Tax Act, supra note 57 for a list of regulations cited.

Exploration Incentive Reg, supra note 54 provides for funding from the Minister to prospectors or exploration companies for approved projects for a variety of activities to "prove" up a mineral resource (see ss 4, 10-14, 16, 22-25). See also Mineral Resources Act, ibid; Tax Credit Reg, supra note 56, ss $10.1,10.2,10.3,10.4,10.5$. Both the prospector's incentive program and the mineral exploration tax credits enable individuals to support mineral resource exploration.

135 Both The Crown Minerals Act, supra note 55, ss 18.1-18.2, as well as the Mineral Resources Act, ibid, s 5.1, enable the Saskatchewan Crown to enter into agreements with Canada, other provinces, and First Nations for information exchange and administrative purposes. This clause could easily be modified to enable agreements for a purpose related to mineral tenure inspections and standards, ranging from 


\section{Disposition of Mineral Rights}

5(1) The Division Chief may, by public advertisement or in such other manner as he considers advisable, invite tenders for mineral rights on such terms and conditions as he deems proper. ${ }^{136}$

(2) Where tenders have been submitted in compliance with the terms and conditions set forth by the Division Chief, the Division Chief may issue a permit or lease to the person submitting the highest tender or may reject all tenders. ${ }^{137}$

6(1) Notwithstanding section 5, the Division Chief may, with the consent of the council of the band for whose use and benefit lands have been set apart and subject to such terms and conditions as the council of the band may approve, issue a permit or lease with respect to minerals underlying such lands to any person upon application therefor.

(2) Every application for a permit ${ }^{138}$ or lease ${ }^{139}$ shall be accompanied by the fee therefor set out in the schedule payable to the Receiver General.

\section{Permits}

\section{Term of Permit}

7(1) Subject to subsection (2), every permit expires one year from the date upon which it was issued.

(2) Where before the expiration of his permit a permittee makes an application in a form satisfactory to the Supervisor for extension thereof, the Supervisor, upon being satisfied that the permittee has complied with these Regulations, and with the terms and conditions of his permit, shall extend that permit for a period of one year or for such shorter period of time as the permittee may request. ${ }^{140}$

(3) Every application for extension of a permit shall contain

(a) a summary of the work that has been done under the permit and the most recent extension thereof; and

(b) a summary of the work that the permittee proposes to do if the permit is extended.

8 A permittee shall not be entitled to more than three extensions ${ }^{141}$ of his permit unless

(a) the invitation to tender under section 5 or the permit issued under section 6 states that more than three extensions may be granted; or

(b) in the opinion of the Supervisor, the extension of the permit is required to complete exploration work in the permit area and assessment work has been performed satisfactorily.

prospecting through mine closure and reclamation. The only modification would be the disposition of the mineral, in that the mineral itself would be reserved for the "use and benefit of the First Nation." Subsurface Mineral Tenure Reg, supra note 55, s 7.

The Crown Minerals Act, supra note 55, ss 4-6.

Subsurface Mineral Tenure Reg, supra note 55, s 10.1.

Ibid, s 22(1).

Ibid, ss 9(2)-(3). The permit for exploration is only renewed under specific conditions, such as if the permit holder cannot access the lands, if there is a natural disaster, or if government action prevents access.

Thus the total period in which a permit may be issued is four years. 
9 Where, within 30 days after the date upon which a permit expires, the holder of the expired permit makes an application to the Supervisor for reinstatement and extension of that permit, the Division Chief may at the request of the Supervisor reinstate and extend that permit for a period not exceeding one year from the date upon which it expired.

Rental

10(1) A permittee shall pay, unless otherwise provided in the invitation to tender under section 5 or in the permit issued under section 6 , the rent for the initial term of his permit or an extension thereof, as the case may be, in advance to the Receiver General and such rent shall be payable at the rate of ${ }^{142}$

(a) $\$ 0.25$ for each acre in the permit area in respect of the initial term of his permit;

(b) \$0.04 per month for each acre in the permit area in respect of each of the first, second and third extensions of his permit; and

(c) $\$ 0.08$ per month for each acre in the permit area in respect of any further extension.

(2) Where a permittee is issued a lease pursuant to section 19, the Division Chief shall direct the return to the permittee of any rent paid pursuant to subsection (1) that applies to the unexpired term of the permit or extension thereof, as the case may be, that was issued for the area taken under the lease. ${ }^{143}$

Security Deposit

11(1) No permit shall be issued to any person unless that person has deposited with the Division Chief a security deposit in such amount or at such rate, if any, as may be specified in the invitation to tender under section 5 or in the permit to be issued under section $6 .{ }^{144}$

(2) A security deposit shall be in the form of money, bonds or promissory to the Receiver General on demand at a chartered bank or in such other form as the Division Chief deems proper.

12 Where a permit expires or is surrendered, the Division Chief, upon being satisfied that the permittee has complied with these Regulations and with the terms and conditions of his permit, shall direct that any security deposit deposited pursuant to subsection 11(1) be returned to the permittee.

Assessment Work

13(1) During the initial term of his permit or during any extension thereof, as the case may be, every permittee shall perform assessment work acceptable to the Supervisor, of the value of

(a) $\$ 0.50$ for each acre in the permit area during the initial term of his permit, ${ }^{145}$ and

(b) $\$ 1$ for each acre in the permit area during the term of each extension of his permit,

142 Subsurface Mineral Tenure Reg, supra note 55, ss 10(1)-(2).

143 In Saskatchewan, if the permittee withdraws their permit, they are not refunded the rent already paid. See ibid, s 16(2).

144 Mineral Environmental Protection Reg, supra note 61, ss 12-15.

145 Subsurface Mineral Tenure Reg, supra note 55, s 11(1). 
or of such other value as may be specified in the invitation to tender under section 5 or in the permit issued under section $6 .^{146}$

(2) Where, in his opinion, assessment work performed near a permit area serves to evaluate the mineral potential of the permit area, the Supervisor may deem the whole or any part of the value of that work to be assessment work performed in the permit area. ${ }^{147}$

14(1) Where assessment work of the value required under subsection 13(1) is not performed, the permittee shall make a cash payment to the Receiver General in an amount equal to the difference between the value of assessment work performed and the value of assessment work required to be performed. ${ }^{148}$

(2) Where the value of assessment work performed during the term of a permit or an extension thereof exceeds the value of assessment work required to be performed pursuant to subsection 13(1), the Supervisor may value of the assessment work performed to the value of the assessment work required to be performed ${ }^{149}$

(a) pursuant to subsection 13(1) during any extension or further extension of the permit; or

(b) pursuant to any lease or leases that the permittee may acquire with respect to all or any part of his permit area.

15(1) Every permittee shall, within 90 days following the expiry of his permit and following any extension thereof, forward to the Supervisor a certified statement in duplicate itemizing the assessment work performed and the cost of performing such work during the term of his permit and any extension thereof together with any cash payment that may be required pursuant to subsection $14(1) .{ }^{150}$

(2) Every permittee shall, within six months following the expiry of his permit and following any extension thereof, forward to the Supervisor copies in duplicate of all maps and technical information that serve to record the assessment work performed for the term of his permit and any extension thereof together with a report of the results obtained from the performance of that assessment work.

(3) Where the Supervisor is not satisfied with the statements, maps or technical information submitted under subsection (1) or (2), he may require the permittee to submit additional information.

Test Shipments

16(1) Subject to subsection (2), no permittee shall produce minerals from his permit area.

(2) A permittee may, with the written consent of the Supervisor and subject to such terms and conditions as the Supervisor may prescribe in writing, produce and ship reasonable amounts of minerals for testing purposes only. 


\section{Leases $^{151}$}

Selection

17 Where a permittee, during the term of his permit or any extension thereof, desires to obtain a lease in respect of his permit area or any part thereof, he shall make an application in duplicate therefor to the Supervisor. ${ }^{152}$

18(1) An application for a lease referred to in section 17

(a) shall be in a form satisfactory to the Division Chief;

(b) shall contain a legal description in accordance with subsection (2) or (3) of the lands in respect of which a lease is desired; ${ }^{153}$ and

(c) shall be accompanied by

(i) the fee therefor set out in the schedule payable to the Receiver General, ${ }^{154}$ and

(ii) the rental for the first year of the lease in accordance with section $24 .{ }^{155}$

(2) Subject to subsection (3), lands referred to in subsection (1) shall be described by

(a) section, legal subdivision, lot or aliquot part of a lot if such lands lie within a subdivided area; or

(b) projected section, legal subdivision, lot or aliquot part of a lot if such lands do not lie within a subdivided area.

(3) Where the boundaries of a permit area or part thereof in respect of which a lease is desired do not correspond with a township survey or other legal survey or any projection thereof, the Division Chief may allow the land therein to be described by means of irregular boundaries.

19 Where a permittee has made an application for a lease in accordance with sections 17 and 18 and has complied with these Regulations and with the terms and conditions of his permit, the Division Chief shall issue a lease to him. ${ }^{156}$

Entitlement

20 Every lessee who has complied with the provisions of these Regulations is entitled to all minerals found within his lease area, subject to any condition of his permit or lease acquired under section 5 or $6 .{ }^{157}$

Surveys

21 Where, in the opinion of the Division Chief, it is necessary that lands in respect of which a lease is desired be surveyed for the purpose of issuing a lease pursuant to section 19, the Division Chief may require the applicant for the lease to have the boundaries of such lands surveyed by a commissioned land surveyor acting under instructions from the Surveyor General of Canada.

151 Ibid, Part IV.

152 The Crown Minerals Act, supra note 55, s 27.2.

153 Subsurface Mineral Tenure Reg, supra note 55, Part IV.

154 Ibid, Appendix.

155 Lease Reg, supra note 55, s 3.

156 Subsurface Mineral Tenure Reg, supra note 55, s 19.

157 Ibid, s 20. 
22(1) Where a lease area is not surveyed before the issuance of a lease, but is subsequently surveyed by a land surveyor acting under the instructions of the Surveyor General of Canada, the Division Chief may amend the description in the lease to conform to the description supplied by the Surveyor General of Canada.

(2) Where the description in a lease is amended under subsection (1), the Division Chief shall forward to the lessee, by registered mail, a copy of the amended description.

(3) The description of lands in a lease referred to in subsection (1) shall be deemed to have been amended on the 30th day after a copy of the amended description was forwarded to the lessee by registered mail.

Term of Lease

23(1) Subject to subsection (2), every lease expires 10 years from the date upon which it was issued unless otherwise provided in the invitation to tender under section 5 or in the lease issued under section 6 or pursuant to section $19 .^{158}$

(2) Where, before the expiration of a lease or a renewal thereof, a lessee applies to the Division Chief for a renewal or further renewal of the lease, and where the lessee has complied with these Regulations and with the terms and conditions of the lease or renewal thereof, the Division Chief shall issue the renewal or further renewal of the lease ${ }^{159}$

(a) for such renewal term as may be specified in the lease or, if no renewal term is specified in the lease, for a term of 10 years; or

(b) for such shorter term than that specified in paragraph (a) as the lessee may request.

(3) For the purposes of subsection (2), the Division Chief may allow a lessee to group two or more of his leases within any one reserve.

(4) [Revoked, SOR/90-468, s. 1]

(5) Every application for renewal of a lease shall be accompanied by the fee therefor set out in the schedule payable to the Receiver General.

Rental

24 A lessee shall pay annual rental in advance to the Receiver General at the rate of $\$ 2$ for each acre in the lease area or at such other rate as may be specified in the invitation to tender under section 5 or in the lease issued under section 6 or pursuant to section $19 .{ }^{160}$

$\begin{array}{ll}158 & \text { Ibid, s } 21 . \\ 159 & \text { Ibid, Part V. } \\ 160 & \text { Ibid, s 22. }\end{array}$


Security Deposit

25(1) No lease shall be issued to any person unless that person has deposited with the Division Chief a security deposit in such amount or at such rate, if any, as may be specified in the invitation to tender under section 5 or in the lease to be issued under section 6 or pursuant to section $19 .{ }^{161}$

(2) A security deposit shall be in the form of money, bonds or promissory notes payable to the Receiver General on demand at a chartered bank or in such other form as the Division Chief deems proper.

26 Where the Division Chief is satisfied that a lessee has complied with these Regulations and with the terms and conditions of his lease or any renewal thereof, he may, during the term of the lease, and shall, on the expiry or surrender thereof, direct that the security deposit or a portion thereof deposited pursuant to subsection $25(1)$ be returned to the lessee. ${ }^{162}$

Assessment Work

27(1) During each year of the term of his lease and any renewal thereof, every lessee shall perform assessment work acceptable to the Supervisor of the value of $\$ 2$ for each acre in the lease area, or of such other value as may be specified in the invitation to tender under section 5 or in the lease issued under section 6 or pursuant to section $19 .{ }^{163}$

(2) Where in his opinion assessment work performed near a lease area serves to evaluate the mineral potential of the lease area, the Supervisor may deem the whole or any part of the value of that work to be assessment work performed in the lease area.

28(1) Where, during any year of a lease, assessment work of the value required under subsection 27(1) is not performed, the lessee shall make a cash payment to the Receiver General in an amount equal to the difference between the value of assessment work performed during that year and the value of the assessment work required to be performed. ${ }^{164}$

(2) Where the value of assessment work performed during any year of a lease exceeds the value of assessment work required to be performed under subsection (1), the Supervisor may credit the excess value of the assessment work performed to the value of the assessment work required to be performed pursuant to subsection 27(1) in any succeeding year or years up to 10 years from the year in which the assessment work was performed.

29(1) Every lessee shall, within 90 days following the completion of each year of the term of his lease or any renewal thereof, forward to the Supervisor a certified statement in duplicate itemizing the assessment work performed and the cost of performing such work during the year most recently completed, together with any cash payment that may be required pursuant to subsection $28(1) .{ }^{165}$

Mineral Environmental Protection Reg, supra note 61, ss 14-15.

Subsurface Mineral Tenure Reg, supra note 55, s 24.

Ibid, $\mathrm{s} 43$.

Ibid, $\mathrm{s} 44$

Ibid, $\mathrm{s} 45$. 
(2) Every lessee shall, within six months following the completion of each year of the term of his lease or any renewal thereof, forward to the Supervisor copies in duplicate of all maps and technical information that serve to record the assessment work performed for the year most recently completed, together with a report of the results obtained from the performance of that assessment work.

30 [Revoked, SOR/90-468, s. 2]

Royalties $^{166}$

31 Unless otherwise specified in the invitation to tender under section 5 or in the lease issued pursuant to section 6 or 19, every lessee shall pay royalties on all minerals to which he is entitled that have been obtained from his lease area at the rate of five per cent of

(a) the gross revenue from the mineral output at the pithead, where the minerals are sold at the lease area before treatment; or

(b) the market value of the mineral output at the pithead, where the minerals are not sold at the lease area before treatment.

32 Notwithstanding section 31 , the rate of royalty may be altered by agreement between the Division Chief ${ }^{167}$ and the lessee from a rate based on a percentage of the gross revenue or of the market value to the equivalent rate per ton or per cubic yard of the mineral output at the pithead.

33 Any royalty rate based upon a weight or measure of mineral output shall be adjusted annually to conform to changes in a price index or other index that is published by Statistics Canada and is chosen by the Division Chief.

34(1) During the term of his lease and any renewal thereof, a lessee shall forward to the Supervisor within 30 days after the expiry of each period of production a royalty payment in favour of the Receiver General in respect of that period together with a statement in duplicate showing the production and sales figures upon which the payment has been calculated.

(2) Where the Supervisor is not satisfied with the amount of a royalty payment or with a statement forwarded by a lessee pursuant to subsection (1), he may require the lessee to submit further particulars in relation to the statement and, if then required by the Supervisor, the lessee shall adjust the amount of the royalty payment.

(3) A period of production consists of the three calendar months ending on the last day of March, June, September and December or of such other period of time as the Supervisor may determine.

Notice of Production

35 Every lessee, within 10 days from the commencement of production of any mineral from his lease area, shall

(a) notify the Supervisor of the commencement of production; and 
(b) submit to the Supervisor such information with respect to his mining operations and production as the Supervisor may require.

Penalty and Cancellation

36(1) Where a lessee fails to pay rental as required by section 24 or to surrender his lease within 30 days from the date on which the rental becomes payable, he is liable to a penalty of five per cent of the amount of his rental. ${ }^{168}$

(2) Notwithstanding subsection (1), where in the opinion of the Division Chief a lessee has failed in respect of his lease to comply with any provision of these Regulations, the Division Chief may forward to the lessee written notice by registered mail advising him that unless he commences to remedy the failure within 30 days from the date of the mailing of the notice and continues diligently to remedy the failure his lease may be cancelled by the Minister.

(3) Where a lessee has received a notice pursuant to subsection (2), he may, within 30 days from the date of the mailing of the notice, make written application to the Minister for a hearing to consider reasons why his lease should not be cancelled.

(4) Upon receipt of an application made pursuant to subsection (3), the Minister shall appoint a time and place for a hearing and shall notify the lessee by registered mail of the time and place of the hearing not less than 10 days before the date thereof.

(5) Where, in the opinion of the Minister, a lessee has failed to comply with the requirements of a notice mailed to him pursuant to subsection (2), or at a hearing held pursuant to this section does not show adequate reason why his lease should not be cancelled, the Minister shall cancel his lease.

\section{General}

Grouping

37 The Division Chief may authorize the grouping of ${ }^{169}$

(a) a permit area or a lease area within a reserve with other permit areas or lease areas within the same reserve for the purpose of

(i) providing a security deposit required under section 11 or 25 , and

(ii) assessment work required to be performed under sections 13 and 27; and

(b) a lease area within a reserve with other lease areas within the same reserve for the purpose of qualifying for a renewal under subsection 23(2) or (3).

38 The Minister may authorize the grouping of a permit area or a lease area in a reserve with a permit area or lease area in another reserve or with a tract of land outside a reserve for the purpose of development or production of minerals under these Regulations, where councils of the bands for whose use and benefit the lands have been set apart in which the permit areas or lease areas are located, have approved a formula for 
determining the participation of the bands in revenues and other benefits derived from such development or production of minerals.

Assignment

39 (1) A permittee or lessee may assign his permit or lease or any interest therein with the approval of the Minister.

(2) Where an assignment of a permit or lease

(a) has been approved by the Minister,

(b) is unconditional, and

(c) is accompanied by the registration fee set out in the schedule payable to the Receiver General,

the assignment shall be registered in the register kept pursuant to section 55 of the Act. ${ }^{170}$

Surrender

40(1) Where a permittee or lessee has complied with these Regulations and with the terms and conditions of his permit or lease, he may at any time surrender all or part of his permit area or lease area. ${ }^{171}$

(2) Subject to subsection 10(2), where a permit or lease is surrendered under subsection (1), no rental paid in relation to that permit or lease shall be returned to the permittee or lessee.

Use of Land Surface

41 Where a person requires entry to a reserve in respect of which minerals have been surrendered or where a permittee or lessee requires use of land surface in a reserve for the purpose of development or production of minerals, he shall obtain a right of entry or right to use the land in accordance with any provisions that may be made by the Minister under the Act. ${ }^{172}$

Inspection

42(1) The Supervisor may

(a) enter upon and inspect any permit area, lease area or buildings and equipment thereon;

(b) require a permittee or lessee to produce any technical, financial and other records relating to the exploration for or production of minerals from his permit area or lease area; and

(c) take samples of minerals being produced and carry out any examination that, in his opinion, is necessary.

(2) Every permittee or lessee shall render such assistance as the Supervisor may require in the performance of his duties. ${ }^{173}$

The Crown Minerals Act, supra note 55, ss 27.3-27.56; The Mineral Tenure Registry Regulations, RRS c C-50.2, Reg 27.

Subsurface Mineral Tenure Reg, supra note 55, ss 23-24.

The Crown Minerals Act, supra note 55, s 19.

Subsurface Mineral Tenure Reg, supra note 55, ss 13-14, 43. 
Plans

43(1) Upon the termination of his permit or extension thereof or of his lease or renewal thereof and at such other times as the Supervisor may request, a permittee or lessee, as the case may be, shall submit to the Supervisor plans and sections that show ${ }^{174}$

(a) the location of all mine workings; ${ }^{175}$

(b) the average valuable mineral content of all mine headings, backs and faces not currently being worked; and

(c) the surface and underground plant, roads, railways, buildings and other structures or works situated in the permit area or lease area.

(2) All plans and sections submitted pursuant to subsection (1) shall be submitted in duplicate and shall be drawn on a scale of one inch to 100 feet or on such other scale as the Supervisor may determine.

(3) Where plans and sections submitted pursuant to subsection (1) are not satisfactory to the Supervisor, the Supervisor may require the permittee or lessee to submit further plans and sections.

Information Confidential

44 Any technical information submitted by a permittee or lessee pursuant to these Regulations shall not, without the written consent of the permittee or lessee, be disclosed unless that information ${ }^{176}$

(a) relates only to a permit area or a portion thereof in respect of which the permit has expired or has been surrendered; or

(b) relates only to a lease area or a portion thereof in respect of which the lease has expired or has been surrendered or cancelled.

Payment of Tax

45 Every permittee and every lessee shall pay all rates, assessments and taxes in respect of his permit area or lease area, and in respect of his operations under his permit or lease. ${ }^{177}$

Appeals

46(1) Every permittee and every lessee may appeal to the Minister from any decision of the Division Chief or Supervisor, other than a decision made under section 5,6 or 19.

(2) Where an appeal is made under subsection (1), the Minister may make such order or declaration as he deems proper.

Ibid, s 100.

In Saskatchewan, tailing ponds and tailing disposal areas are managed separately and remain the property of the mining venture that created them. There are specific rules regarding the tailing disposal areas, and if they are mined, a royalty is assessed and paid to the Crown. See General Regulations (Tailing Disposal Area), supra note 55; The Crown Minerals Act, supra note 55.

Subsurface Mineral Tenure Reg, supra note 55, s 46.

Mineral Tax Act, supra note 57; Sodium Chloride Tax Reg, supra note 57; Potash Tax Reg, supra note 57. 


\section{Schedule}

Fees $^{178}$

Column I

Column II

1 Application for permit or lease

. $\$ 20$

2 Registration of assignment of permit or lease .... 20

3 Application for renewal of lease .......... 20 
APPENDIX II:

TABle OF Treaties ANd CoRresponding Mineral Titles

\begin{tabular}{|c|c|c|}
\hline AREA & TREATY & Mineral TITLE AND/OR CONDITIONS \\
\hline & & Indian Mining Regulations, supra note 1. \\
\hline \multirow[t]{6}{*}{ Ontario } & Six Nations. & $\begin{array}{l}\text { "Use and Benefit" - see "Grant - Governor Haldimand } \\
\text { to the Six Nations," ( } 25 \text { October 1784), online: } \\
<\text { collectionscanada.gc.ca/pam_archives/index.php?fuse } \\
\text { action=genitem.displayItem\&lang=eng\&rec_nbr=39724 } \\
74>\text {. }\end{array}$ \\
\hline & Robinson - Superior. & "Use and Benefit" \\
\hline & Robinson Huron. & "Use and Benefit" \\
\hline & Treaty Nos 3, 5, 9 & "Use and Benefit" \\
\hline & $\begin{array}{l}\text { Reserves created after } 1923 \\
\text { and Adhesion to Treaty } 9 .\end{array}$ & $\begin{array}{l}\text { Canada Ontario Reserve Act, supra note } 39 \text {, ss 5-6; } \\
\text { Indian Lands Agreement, supra note } 38 \text {, Schedule, ss } \\
\text { 3(a), (d), (f), (j). }\end{array}$ \\
\hline & Reserves created after 1991. & $\begin{array}{l}\text { Three First Nations have concluded Treaty Land } \\
\text { Entitlement agreements with Ontario and Canada and } \\
\text { the assignment of mineral rights follows the } \\
\text { Ontario/Canada Treaty Land Entitlement Process. See } \\
\text { Chapleau Creek Cree First Nation Final Agreement, } \\
\text { supra note 41, ss 7.1-7.5; Chapleau Creek Ojibwa First } \\
\text { Nation Final Agreement, supra note 41, ss 7.1-7.5; } \\
\text { Misaanjigamiing First Nation Final Agreement, } \\
\text { supra note 41, ss 7.1-7.5. }\end{array}$ \\
\hline $\begin{array}{l}\text { Atlantic } \\
\text { Provinces }\end{array}$ & $\begin{array}{l}\text { Reserves in Nova Scotia, } \\
\text { New Brunswick, and } \\
\text { Prince Edward Island. }\end{array}$ & $\begin{array}{l}\text { NB Reserves Act, supra note } 42, \mathrm{~s} 5 ; \text { NS Reserves Act, } \\
\text { supra note } 43, \mathrm{~s} 5 . \text { On the Morrell and Scotchfort } \\
\text { Reserves, Prince Edward Island owns the rights and the } \\
\text { revenue is split } 50 \text { percent with the First Nation. On the } \\
\text { Lennox Island No.1 Reserve and Rocky Point Reserve, } \\
\text { the mineral title is vested in the First Nation. }\end{array}$ \\
\hline \multicolumn{3}{|l|}{$\begin{array}{l}\text { The Prairies } \\
\text { Alberta, } \\
\text { Saskatchewan, and } \\
\text { Manitoba }\end{array}$} \\
\hline \multirow[t]{2}{*}{$\begin{array}{l}\text { Treaty Nos } 1,2,4,5 \text {, } \\
6,7,8,10\end{array}$} & Before 1930. & "Use and Benefit" \\
\hline & After 1930. & $\begin{array}{l}\text { Alberta Natural Resources Act, supra note 19, s } 10 \text {; The } \\
\text { Manitoba Natural Resources Act, supra note 19, s 11; } \\
\text { The Saskatchewan Natural Resources Act, supra note } \\
\text { 19, s } 10 \text {. }\end{array}$ \\
\hline
\end{tabular}




\begin{tabular}{|c|c|c|}
\hline AREA & Treaty & Mineral TITLE AND/OR CONDITIONS \\
\hline & Treaty Land Entitlement. & $\begin{array}{l}\text { Saskatchewan Treaty Land Entitlement Act, SC } \\
\text { 1993, c 11; Claim Settlements (Alberta and } \\
\text { Saskatchewan) Implementation Act, supra note 27; } \\
\text { Manitoba Claim Settlements Implementation Act, supra } \\
\text { note 28; not under the Indian Mining Regulations. }\end{array}$ \\
\hline \multirow[t]{3}{*}{ British Columbia } & Douglas Treaties \& Treaty 8. & $\begin{array}{l}\text { BC Reserves Mineral Resources Act, supra note } 48 . \\
\text { Fifty percent of all purchase money, rent, recording } \\
\text { fees, royalty, or otherwise in respect of any sale or other } \\
\text { disposition of minerals and mineral claims, in, upon, or } \\
\text { under such Reserves, together with all licence, permit, } \\
\text { or other fees. Fort Nelson Indian Reserve Minerals } \\
\text { Revenue Sharing Act, SC 1980-83, c 38, ss 2-3, 6-7. }\end{array}$ \\
\hline & Treaties from 1990 onwards. & $\begin{array}{l}\text { British Columbia First Nations who have concluded } \\
\text { Treaties with British Columbia and Canada hold } \\
\text { ownership of mineral resources; but British Columbia } \\
\text { retains permitting, management rights, and } \\
\text { environmental standards. Maa-nulth First Nations Final } \\
\text { Agreement, supra note 16, ss 4.1-4.1.5; Nisga'a Final } \\
\text { Agreement (Ottawa: Minister of Indian Affairs and } \\
\text { Northern Development, April 1999), ss 19-21; Tla'amin } \\
\text { Final Agreement (Ottawa: Minister of Indian Affairs } \\
\text { and Northern Development, 2014), ss 67-74, 79(a), 80; } \\
\text { Tsawwassen First Nation Final Agreement (Ottawa: } \\
\text { Minister of Indian Affairs and Northern Development, } \\
\text { December 2007), ss 22-25. }\end{array}$ \\
\hline & Aboriginal Title Lands. & $\begin{array}{l}\text { Aboriginal title encompasses mineral rights. See } \\
\text { Delgamuukw, supra note } 15 \text {. }\end{array}$ \\
\hline \multicolumn{3}{|l|}{ The Territories } \\
\hline Yukon & $\begin{array}{l}\text { Yukon Umbrella Agreement, } \\
\text { supra note } 16 .\end{array}$ & $\begin{array}{l}\text { On settlement lands, mineral title is vested in the } \\
\text { First Nation, permitting is deferred to the Yukon. See ss } \\
\text { 18.1-18.2. }\end{array}$ \\
\hline Nunavut & $\begin{array}{l}\text { Agreement between the } \\
\text { Inuit of the Nunavut Settlement } \\
\text { Area and Her Majesty the } \\
\text { Queen in right of Canada } \\
\text { (Ottawa: Minister of Indian } \\
\text { Affairs and Northern } \\
\text { Development, May 1993). }\end{array}$ & $\begin{array}{l}\text { On settlement lands, mineral title is vested in the } \\
\text { Nunavut Inuit, royalties are conferred, but not } \\
\text { administration of the properties. See art } 17 \text {, Part } 1 \text {, } \\
\text { s 17.1(b); art } 27 \text {. }\end{array}$ \\
\hline
\end{tabular}




\begin{tabular}{|c|c|c|}
\hline AREA & TREATY & Mineral TitLE AND/OR CONDITIONS \\
\hline \multirow[t]{4}{*}{$\begin{array}{l}\text { Northwest } \\
\text { Territories }\end{array}$} & $\begin{array}{l}\text { Inuvialuit Final Agreement, } \\
\text { supra note } 16 .\end{array}$ & $\begin{array}{l}\text { On settlement lands, mineral title is vested in the } \\
\text { Inuit, royalties are conferred, but not the administration } \\
\text { of the properties. See ss } 7(1), 7(99) \text {. }\end{array}$ \\
\hline & $\begin{array}{l}\text { Sahtu Dene Agreement, } \\
\text { supra note } 16 .\end{array}$ & $\begin{array}{l}\text { On settlement lands, mineral title is vested in the } \\
\text { First Nation, permitting is deferred to the Northwest } \\
\text { Territories. See ss } 10.12,22 \text {. }\end{array}$ \\
\hline & $\begin{array}{l}\text { Gwich'in Agreement, } \\
\text { supra note } 16 .\end{array}$ & $\begin{array}{l}\text { On settlement lands, mineral title is vested in the } \\
\text { First Nation, permitting is deffered to the Northwest } \\
\text { Territories. See ss } 18.1 .2,19 \text {. }\end{array}$ \\
\hline & $\begin{array}{l}\text { Tlicho Land Agreement, } \\
\text { supra note } 16 .\end{array}$ & $\begin{array}{l}\text { On settlement lands, mineral title is vested in the } \\
\text { First Nation, permitting is deferred to the Northwest } \\
\text { Territories. See chs } 23,25 \text {. }\end{array}$ \\
\hline \multirow[t]{3}{*}{ Quebec } & $\begin{array}{l}\text { James Bay Agreement, } \\
\text { supra note } 16 .\end{array}$ & $\begin{array}{l}\text { Mineral title is vested in Quebec, soapstone and } \\
\text { other carving stone may be used by First Nation and } \\
\text { Inuit People. See ss } 5 \cdot 1.10 \text { (a)-5.1.10(c). }\end{array}$ \\
\hline & James Bay Agreement, ibid. & $\begin{array}{l}\text { Mineral title is vested in Quebec, soapstone and } \\
\text { other carving stone may be used by Inuit People. See } \\
\text { ss } 5.1,5.3 \text {. }\end{array}$ \\
\hline & $\begin{array}{l}\text { The Northeastern Quebec } \\
\text { Agreement, supra note } 16 .\end{array}$ & $\begin{array}{l}\text { Mineral title is vested in Quebec, soapstone and } \\
\text { other carving stone may be used by the Naskapi People. } \\
\text { Compensation and consent is required for new mineral } \\
\text { exploration or development. See ss 5.1.9.1- 5.1.9.3, } \\
\text { 5.2.5.2. }\end{array}$ \\
\hline $\begin{array}{l}\text { Newfoundland \& } \\
\text { Labrador }\end{array}$ & $\begin{array}{l}\text { Labrador Inuit Land Claims } \\
\text { Agreement, supra note } 16 .\end{array}$ & $\begin{array}{l}\text { Mineral title is retained by the province, and a } \\
\text { percentage of the royalties are transferred to the } \\
\text { Labrador Inuit. See ss } 4.4 .1,4.11,4.13,23,25 \text {. }\end{array}$ \\
\hline $\begin{array}{l}\text { Quebec, Nunavut \& } \\
\text { Newfoundland }\end{array}$ & $\begin{array}{l}\text { Nunavik Inuit Land Claims } \\
\text { Agreement, supra note } 16 .\end{array}$ & $\begin{array}{l}\text { The Nunavik Inuit hold mineral title, but the } \\
\text { administration is a tri-partied relationship between } \\
\text { Nunavut, Newfoundland, and Quebec. See art 8, s 8.3. } \\
\text { 1(c); art 9; Part 12.5; Part 15, s 15.1.2; art 15. }\end{array}$ \\
\hline
\end{tabular}


APPENDIX III:

RoYAltiEs RESUlting FroM VARIOUS ACTS AND REGULATIONS

\begin{tabular}{|c|c|c|}
\hline \multicolumn{3}{|l|}{$\begin{array}{l}\text { Royalty on } \\
\text { Minerals }\end{array}$} \\
\hline & Saskatchewan & First Nation \\
\hline Statute & $\begin{array}{l}\text { The Crown Minerals Act, supra note 55, ss 1-16.1, 22.1(1.1); } \\
\text { Mineral Resources Act, supra note 56; Mineral Tax Act, supra note } \\
57 .\end{array}$ & Indian Act, supra note 2. \\
\hline Regulations & $\begin{array}{l}\text { Crown Royalty Reg, supra note 55; Tax Credit Reg, supra note 56; } \\
\text { Mineral Rights Tax Reg, supra note 57; Coal Tax Reg, supra note } \\
\text { 57; Sodium Chloride Tax Reg, supra note 57; Potash Tax Reg, } \\
\text { supra note } 57 .\end{array}$ & $\begin{array}{l}\text { Indian Mining Regulations, supra } \\
\text { note } 1 \text {, ss } 31-34 .\end{array}$ \\
\hline $\begin{array}{l}\text { Mining tax or } \\
\text { royalty }\end{array}$ & $\begin{array}{l}5 \text { percent cumulative sales up to } 1 \mathrm{M} \text { troy oz of precious metals or } \\
1 \mathrm{M} \text { metric tonnes of base metals; } 10 \text { percent above thresholds. }\end{array}$ & $\begin{array}{l}5 \text { percent of gross revenue at the } \\
\text { pithead or market value of the } \\
\text { output at the pithead. Or, may be } \\
\text { altered to reflect market value, or } \\
\text { a rate per tonne or yard of mineral } \\
\text { at the pithead. See ss } 31-34 \text {. }\end{array}$ \\
\hline $\begin{array}{l}\text { Mining tax } \\
\text { exemption on } \\
\text { new mines }\end{array}$ & 10 Year Royalty Payment Holiday for New Mines. & N/A \\
\hline $\begin{array}{l}\text { Depreciation } \\
\text { on Mining }\end{array}$ & 100 percent. & N/A \\
\hline \multirow[t]{2}{*}{$\begin{array}{l}\text { Special } \\
\text { Features }\end{array}$} & 10 Year Payment Royalty Holiday for Mines starting in 2007. & N/A \\
\hline & $\begin{array}{l}150 \text { percent of pre-production expenses are recovered prior to any } \\
\text { royalty payment. }\end{array}$ & $\mathrm{N} / \mathrm{A}$ \\
\hline $\begin{array}{l}\text { Exploration } \\
\text { Credits }\end{array}$ & 150 percent. & N/A \\
\hline $\begin{array}{l}\text { Pre-Expense } \\
\text { Deductible }\end{array}$ & 100 percent. & N/A \\
\hline
\end{tabular}

